\title{
Application of a vital staining method to measure feeding rates of field ciliate assemblages on a harmful alga
}

\author{
Takashi Kamiyama* \\ Coastal Productivity Division, National Research Institute of Fisheries and Environment of Inland Sea, Maruishi, Ohno, Saeki, \\ Hiroshima 739-0452, Japan
}

\begin{abstract}
The fluorescently labeled algae (FLA) technique using a vital green fluorescent stain CMFDA (5-chloromethylfluorescein diacetate) was applied to investigate the feeding activities of a field ciliate assemblage on a harmful alga, Heterocapsa circularisquama. Using epifluorescence under interference blue-light excitation improved the limitations noted in the original protocol ( $\mathrm{Li}$ et al. 1996; Aquat Microb Ecol 10: 139-147), which are due to the occurrence of green autofluorescence similar to that of CMFDA-labeled prey in natural assemblages and in food vacuoles of field protists. CMFDAlabeled $H$. circularisquama were ingested by the tintinnid ciliate Favella taraikaensis at the same rate as non-labeled alga, indicating that the staining with CMFDA did not influence the feeding activity of the ciliates. In an in situ feeding experiment, more than 6 species of heterotrophic and mixotrophic ciliates were shown to be able to feed on $H$. circularisquama, and the ingestion rates of 2 species were estimated (1.08 and 1.83 cells ind.$^{-1} \mathrm{~h}^{-1}$ ). The FLA method with CMFDA is effective in measuring the feeding activities of ciliates and is applicable to the estimation of the grazing impact of ciliate assemblages on $H$. circularisquama populations in natural assemblages.
\end{abstract}

KEY WORDS: FLA - CMFDA - Ciliate · Feeding - Harmful alga $\cdot$ Heterocapsa circularisquama

To clarify the mechanisms by which harmful algal blooms occur, it is essential to understand the role of their grazers. In particular, herbivorous ciliates and heterotrophic dinoflagellates are important as consumers for nano-planktonic harmful algae (Caron et al. 1989, Buskey \& Hyatt 1995. Nakamura et al. 1995, 1996, Kamiyama 1997). To date the feeding activities of some ciliates on harmful algae have been reported from laboratory experiments (Hansen 1989, 1995, Kami-

- Present address: National Research Institute of Fisheries Science, 2-12-4, Fukuura, Kanazawa, Yokohama, Kanagawa 236-8648, Japan. E-mail: kamiyama@affrc.go.jp yama 1997, Jeong et al. 1999). However, since the number of ciliate species that one can culture under laboratory conditions is limited, it is desirable to measure the feeding activities of field ciliate species on harmful algae using in situ experiments, but such data have scarcely been reported.

Using visually detected surrogate prey is one of the most effective methods for investigating the feeding activity of field herbivorous ciliates. In particular, the development of fluorescently labeled algae (FLA) enabled researchers to readily and accurately measure ingestion rates of marine ciliates on some algae (Rublee \& Gallegos 1989) since some species of ciliates showed chemosensory selectivity for specific algae (Stoecker et al. 1981, 1986, Stoecker 1988, Taniguchi \& Takeda 1988, Verity 1988). However, Putt (1991) reported that the FLA technique with heat-killed algae even caused underestimation of the ingestion rates in some herbivorous ciliates. Live, fluorescently labeled prey using HYD (hydroethidine) (Putt 1991), DAPI (2,4-diamadino-6-phenylindole) (Lessard et al. 1996) and CMFDA (5-chloromethylfluorescein diacetate) (Li et al. 1996) may be desirable alternatives to heat-killed fluorescently labeled prey. Among these vital stains, CMFDA may be the most effective dye for protists ( $\mathrm{Li}$ et al. 1996). This is metabolized to an aldehyde-fixable, thiol-conjugated product that is trapped within cells for at least $72 \mathrm{~h}$. Further, the toxicity appears to be extremely low (Li et al. 1996).

However, limitations of this technique were demonstrated in Li et al. (1996). The most serious is the existence of some green auto-fluorescence similar to that of CMFDA-labeled prey in field seawater and in the food vacuoles of field protists. They demonstrated the requirements of CMFDA control treatments. This paper reports that it is possible to improve this technique by modifying the observation method and shows 
that the modified CMFDA technique is effective in estimating the grazing impact of a field ciliate assemblage on a harmful alga.

Materials and methods. Prey alga and ciliates: The harmful dinoflagellate Heterocapsa circularisquama was used as the prey alga. Although this alga is highly toxic for bivalves specifically (Matsuyama et al. 1997), 2 species of tintinnids were found to feed on this alga and to be able to grow actively at a low concentration (<1000 cells $\mathrm{ml}^{-1}$ ) (Kamiyama 1997). A strain of $H$. circularisquama (HA92-1) isolated from Ago Bay, Japan, in December 1992 was maintained in modified SWM3 medium (Chen et al. 1969, Itoh \& Imai 1987). For a preliminary laboratory experiment, the tintinnid ciliate Favella taraikaensis isolated from Hiroshima Bay in April 1999 was used. The strain of this tintinnid was maintained in filtered seawater enriched with $0.1 \mathrm{ml}^{-1}$ of $\mathrm{f} / 2$ iron-EDTA trace metal solution (Stoecker et al. 1988) with a mixture of $H$. triquetra and Gyrodinium sp. as food sources.

Staining with CMFDA: The staining method with the CMFDA dye was basically followed as in Li et al. (1996). A stock solution of CMFDA (50 رM) was prepared by dissolving $1 \mathrm{mg}$ of CMFDA in $0.5 \mathrm{ml}$ of dimethylsulfoxide and then diluting up to an appropriate volume with filtered seawater. This solution was kept in a freezer $\left(-20^{\circ} \mathrm{C}\right)$ until the experiments were carried out. For the experiments, part of the stock solution acclimated to room temperature was inoculated into part of Heterocapsa circularisquama cultures to a final concentration of $1 \mu \mathrm{M}$ ( $\mathrm{Li}$ et al. 1996). This culture was then incubated under dark conditions for $1 \mathrm{~h}$ at $20^{\circ} \mathrm{C}$ for a preliminary feeding experiment and $25^{\circ} \mathrm{C}$ for an in situ feeding experiment. Before the experiments, the percentage of the stained cells to the total $H$. circularisquama cells was determined. Furthermore, I checked whether fixed cells with buffered formaldehyde (final concentration: $2 \%$; Stoecker et al. 1989) were stained or not with the CMFDA.

The stained alga was observed using an inverted microscope (Olympus IX-70) equipped with transmitted light and epifluorescence under interference blue (IB)-light excitation (Olympus U-MNIBA filter set: a 470 to $490 \mathrm{~nm}$ band pass filter, a DM505 dichroic splitting mirror and a BA 515-550 barrier filter).

Preliminary feeding experiment in laboratory: A preliminary experiment was designed to confirm that the CMFDA-labeled alga was grazed by ciliates in the same way as the non-labeled alga. Part of the supernatant water was removed without agitation from a culture of Favella taraikaensis when the density of $F$. taraikaensis reached 15 ind. $\mathrm{ml}^{-1}$. Within the supernatant water there were some algal cells carried over from the stock culture ( 18 cells $\mathrm{ml}^{-1}$ ) but auto-fluorescence due to the food algae was hardly observed in the food vacuoles of $F$. taraikaensis $\left(0.08\right.$ cells ind. $\left.^{-1}\right)$. Sixty milliliters of the supernatant water was poured into a $100 \mathrm{ml}$ flask. CMFDA-labeled and non-labeled Heterocapsa circularisquama were added to the flasks to

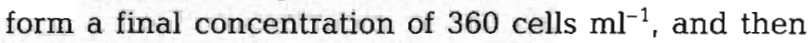
incubation was immediately started under conditions of $20^{\circ} \mathrm{C}$ and $20 \mu \mathrm{mol}$ photon $\mathrm{m}^{-2} \mathrm{~s}^{-1}$. After $5,10,15,20$, $30,40,50 \mathrm{~min}$ of incubation, $2.5 \mathrm{ml}$ of culture was removed from the flasks and transferred into a well of multiple-well plates ( 24 wells) containing $0.25 \mathrm{ml}$ of $20 \%$ buffered formaldehyde for fixation of the tintinnids. Within 5 h, 23 to 27 individuals of F. taraikaensis for each time point were observed with the inverted microscope with transmitted light and epifluorescence, and then the average number of ingested particles was calculated. The auto-fluorescence (red) particles indicating almost all $H$. circularisquama and CMFDAfluorescence (green) particles inside the food vacuoles were counted under blue (B)-light excitation (Olympus U-MWBV filter set: a 400 to $440 \mathrm{~nm}$ band pass filter, a DM500 dichroic mirror and a BA475 barrier filter) and under the IB-light excitation, respectively. Ingestion (= captured prey number per individual) by F. taraikaensis of non-labeled $H$. circularisquama cells was calculated by subtracting the number of green particles from the number of red particles and was compared with ingestion of the CMFDA-labeled cells for each time point.

In situ feeding experiment: A seawater sample was collected from a $1 \mathrm{~m}$ depth layer at a coastal site of western Hiroshima Bay, the Seto Inland Sea, Japan. Two liters of seawater were dispensed into two 11 polycarbonate bottles, the CMFDA-labeled Heterocapsa circularisquama was added to 1 experimental bottle at a final concentration of 700 cells $\mathrm{ml}^{-1}$ and only CMFDA solution diluted with filtered seawater $(5 \mathrm{ml})$ was added to the other control bottle. Bottles were then incubated under conditions of in situ temperature $\left(24.5^{\circ} \mathrm{C}\right)$ and $30 \mu \mathrm{mol}$ photon $\mathrm{m}^{-2} \mathrm{~s}^{-1}$. After 10 and $30 \mathrm{~min}$ of incubation, $300 \mathrm{ml}$ of the water was sampled from each incubated bottle and then divided into three $100 \mathrm{ml}$ bottles containing $10 \mathrm{ml}$ of $20 \%$ buffered formaldehyde for fixation of the field ciliates.

One hundred milliliters of fixed sample was settled in an Utermöhl chamber and ciliates in 3 concentrated samples were observed with the inverted epifluorescence microscope. Microscopic observations were performed with 2 serial steps. Firstly, auto-fluorescence due to chlorophyll $a$ was monitored in food vacuoles of ciliates at a magnification of $150 \times$ using the inverted microscope with the transmitted light and epifluorescence under B-light excitation. Secondly, whether or not the detected particles produced green fluorescence due to the CMFDA was examined under the IBlight excitation. Ingested Heterocapsa circularisquama 


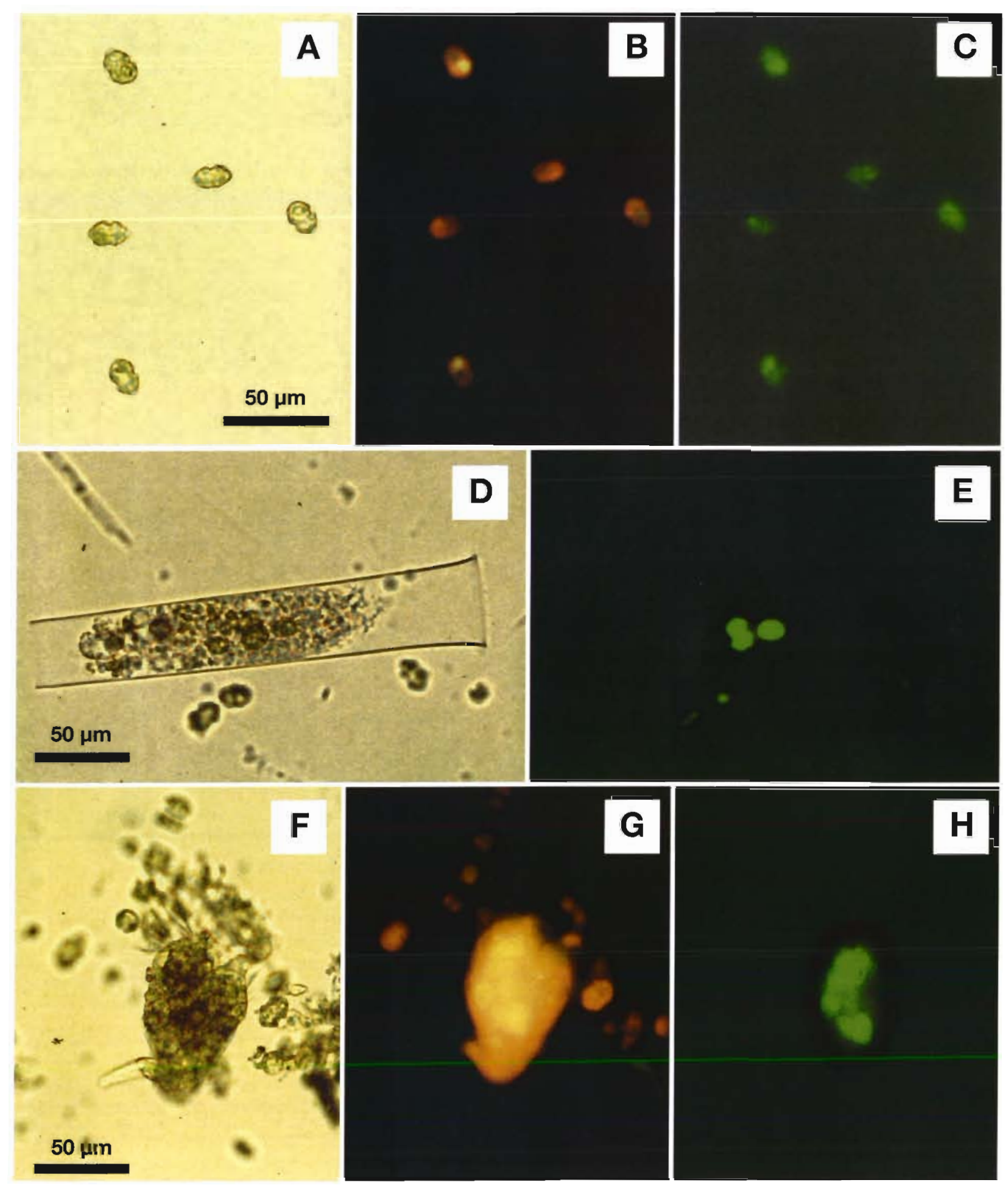

Fig. 1. Photographs of CMFDA-labeled Heterocapsa circularisquama observed (A) with transmitted light and (B) with epifluorescence under blue-light excitation and (C) under interference blue-light excitation; a tintinnid ciliate (Eutintinnus Jususundae) feeding on the CMFDA-labeled $H$. circularisquama observed (D) with transmitted light and (E) with epifluorescence under the interference blue-light excitation; and an aloricate ciliate (Tontonnia sp.) feeding on CMFDA-labeled H. circularisquama observed $(F)$ with transmitted light and $(G)$ with epifluorescence under the blue-light excitation and $(H)$ under the interference blue-light excitation. Note in $(\mathrm{H})$ that only CMFDA fluorescence (green) within the mixotrophic ciliate can be observed under the interference blue-light excitation since red auto-fluorescence due to chlorophyll a is eliminated. Scale bars in (A), (D) and (F) are also applicable to $(B),(C),(E),(G)$ and $(H)$ 


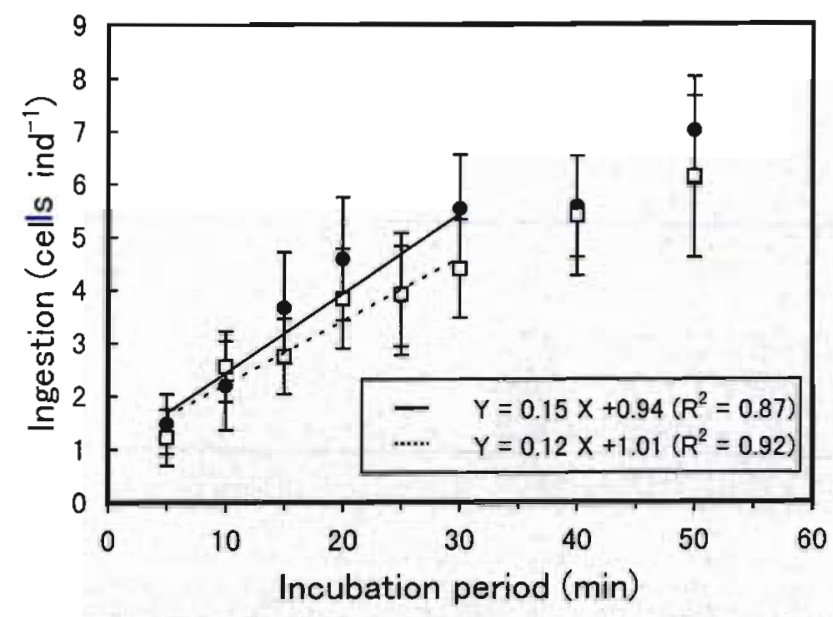

Fig. 2. Ingestion by Favella taraikaensis of CMFDA-labeled (e) and non-labeled (ㅁ) Heterocapsa circularisquama as a function of incubation period. The solid (CMFDA-labeled prey) and dotted lines (non-labeled prey) indicate linear regressions fitted to the data between 5 and $30 \mathrm{~min}$ of incubation. Vertical lines indicate the standard errors of the mean ( $n=23$ to 27 )

cells should be observed under both excitations. Ingestion rates of each ciliate species feeding on $H$. circularisquama was calculated from the increase in the average number of ingested cells between 10 and $30 \mathrm{~min}$ of incubation. In the control bottle, there were no green particles as large as $H$. circularisquama cells within ciliates under the IB-light excitation. Hence, the ingestion rates of the field ciliate assemblage were calculated based only on the results from the experimental bottle.

Results and discussion. Fig. $1 \mathrm{~A}$ to $\mathrm{C}$ shows photographs of Heterocapsa circularisquama stained with CMFDA. Green fluorescence (Fig. 1C) was not as strong as red auto-fluorescence (Fig. 1B) but it was possible to completely eliminate auto-fluorescence under the IB-light excitation (Fig. 1C).

The percentage of CMFDA-labeled cells to the total cell number ( 310 cells) reached $98 \%$, suggesting that almost all cells of CMFDA-labeled Heterocapsa circu- larisquama can be effective for use as a tracer. Fixed $H$. circularisquama cells were not stained with CMFDA. This indicates that the algae in food vacuoles of protists fixed with the buffered formaldehyde are not newly stained with the CMFDA during storage periods.

The average number of CMFDA-labeled Heterocapsa circularisquama ingested by Favella taraikaensis increased linearly with increasing periods of incubation during the first 20 to $30 \mathrm{~min}$ (Fig. 2). This suggests that it is possible to estimate ingestion rates of field ciliates from the increase of ingested algae among more than 2 time points for the first 20 to 30 min of incubation. Similar results are reported in the feeding behavior of ciliates and other protists (e.g. McManus \& Fuhrman 1988). Furthermore, ingestion by ciliates of the CMFDAlabeled $H$. circularisquama was not significantly different from ingestion of the non-labeled $H$. circularisquama at each time point, indicating that staining the alga with CMFDA does not influence the feeding activities of ciliates.

In an in situ feeding experiment in summer, 5 species of tintinnids and 1 species of aloricate ciliate ingested the CMFDA-labeled Heterocapsa circularisquama. Significant ingestion rates could be calculated for Amphorellopsis acuta ( 1.08 cells ind.$\left.^{-1} \mathrm{~h}^{-1}\right)$ and Laboea strobila ( 1.83 cells ind.$^{-1} \mathrm{~h}^{-1}$ ) (Table 1 ). Information on the feeding response of ciliates to $H$. circularisquama is limited to that of Favella taraikaensis and F. azorica (Kamiyama 1997). The result of the present study indicates that other species can also feed on $H$. circularisquama at low densities of this alga. The CMFDAlabeled $H$. circularisquama was readily observed in the food vacuoles of not only heterotrophic ciliates but also mixotrophic ciliates (Fig. 1D to H). However, except for 1 species, it was not possible to identify the species of aloricate ciliates. Hence, it was difficult to estimate the grazing impact of ciliate assemblages in this experiment. The grazing impact of the field ciliate assemblage on $H$. circularisquama and its evaluation will be addressed in another paper.

Table 1. Ingestion rates (mean $\pm \mathrm{SE}$ ) of field ciliates on CMFDA-labeled Heterocapsa circularisquama. nd = not determined; $\mathrm{OD}=$ oral diameter; $\mathrm{ns}=$ not significant; $" \mathrm{p}<0.05$

\begin{tabular}{|c|c|c|c|c|c|}
\hline \multirow[t]{2}{*}{ Ciliate } & \multicolumn{2}{|c|}{10 min of incubation } & \multicolumn{2}{|c|}{30 min of incubation } & \multirow{2}{*}{$\begin{array}{l}\text { Ingestion rate } \\
\text { (cells ind. }{ }^{-1} h^{-1} \text { ) }\end{array}$} \\
\hline & $\begin{array}{l}\text { Abundance } \\
\text { (ind. } 300 \mathrm{ml}^{-1} \text { ) }\end{array}$ & $\begin{array}{l}\text { Ingestion } \\
\text { (cells ind. }^{-1} \text { ) }\end{array}$ & $\begin{array}{l}\text { Abundance } \\
\text { (ind. } 300 \mathrm{ml}^{-1} \text { ) }\end{array}$ & $\begin{array}{l}\text { Ingestion } \\
\text { (cells ind. }^{-1} \text { ) }\end{array}$ & \\
\hline \multicolumn{6}{|l|}{ Tintinnids } \\
\hline Amphorellopsis acuta & 253 & $0.15 \pm 0.39$ & 284 & $0.51 \pm 0.76$ & $1.08 \pm 0.16^{\circ}$ \\
\hline Eutintinnus lususundae & 10 & $1.70 \pm 0.48$ & 6 & $2.50 \pm 1.22$ & $2.40 \pm 1.28 \mathrm{~ns}$ \\
\hline Favella ehrenbergï & 2 & $3.50 \pm 2.12$ & 0 & nd & nd \\
\hline Tintinnopsis cylindria & 26 & $0.23 \pm 0.43$ & 22 & $0.36 \pm 0.66$ & $0.40 \pm 0.47 \mathrm{~ns}$ \\
\hline Tintinnopsis corniger & 10 & $0.10 \pm 0.32$ & 13 & $0.15 \pm 0.38$ & $0.16 \pm 0.44 \mathrm{~ns}$ \\
\hline \multicolumn{6}{|c|}{ Aloricate ciliates (OD > $30 \mu \mathrm{m}$ ) } \\
\hline Laboea strobila & 35 & $0.49 \pm 0.56$ & 21 & $1.10 \pm 1.09$ & $1.83 \pm 0.66^{\circ}$ \\
\hline
\end{tabular}


A characteristic of microscopical observation with the CMFDA technique is illustrated in the present study. Green fluorescent particles observed under IB-light excitation were probably more specific to CMFDA-labeled prey than that observed under the excitation with the Zeiss filter set 487709 (BP450-490 excitation filter, FT510 dichroic beam splitter and LP520 barrier filter) in Li et al. (1996). These authors pointed out the limitations of the CMFDA technique, one of which is the need for a control because there is some green auto-fluorescence observed within the protists in the addition of only CMFDA solution. Although the control treatment in the present study was different from that in Li et al. (1996), which was made from a filtrate of the algal cultures, the results demonstrate that it is not necessary to conduct a control of only CMFDA solution if IB-light excitation can be used. Furthermore, under this excitation it is possible to completely eliminate the effect of auto-fluorescence from chlorophyll a within the mixotrophic ciliates. Although green fluorescence due to CMFDA under this excitation is not very strong, the combination of the 2 filter sets used in the present study can be effective in readily and accurately counting particles in the food vacuoles of heterotrophic and mixotrophic ciliates, and thus enables us to estimate the grazing impact of field ciliate assemblages on stainable prey.

Acknowledgements. I thank Drs Y. Morioka, T. Uchida and $O$. Decamp for their critical reading of the manuscript. This work was partly supported by a grant from the Environmental Agency of Japan.

\section{LITERATURE CITED}

Buskey EJ, Hyatt CJ (1995) Effects of the Texas (USA) 'brown tide' alga on planktonic grazers. Mar Ecol Prog Ser 126: 285-292

Caron DA, Lim EL, Kunze H, Cosper EM, Anderson DM (1989) Trophic interactions between nano- and microzooplankton and the 'brown tide'. In: Cosper EM, Bricelj VM, Carpenter EJ (eds) Novel phytoplankton blooms. Springer-Verlag, New York, p 265-294

Chen LCM, Edelstein T, McLachlan J (1969) Bonnemaisonia hamifera Hariot in nature and in culture. $J$ Phycol 5: 211-220

Hansen PJ (1989) The red tide dinoflagellate Alexandrium tamarense: effects on behaviour and growth of a tintinnid ciliate. Mar Ecol Prog Ser 53:105-116

Hansen PJ (1995) Growth and grazing response of a ciliate feeding on the red tide dinoflagellate Gyrodimium aureolum in monoculture and in mixture with a non-toxic alga. Mar Ecol Prog Ser 121:65-72

Editorial responsibility: John Austin (Assistant Editor), Oldendorf/Luhe, Germany
Itoh K, Imai I (1987) Rafido so (Raphidophyceae). In: Japan fisheries resource conservation association (ed) A guide for studies of red tide organisms. Shuwa, Tokyo, p 122-130 (in Japanese)

Jeong HJ, Shim JH, Lee CW, Kim JS, Koh SM (1999) Growth and grazing rates of the marine planktonic ciliate Strombidinopsis sp. on red-tide and toxic dinoflagellates. J Eukaryot Microbiol 46:69-76

Kamiyama $T$ (1997) Growth and grazing responses of tintinnid ciliates feeding on the toxic dinoflagellate Heterocapsa circularisquama. Mar Biol 128:509-515

Lessard EJ, Martin MP, Montagnes DJS (1996) A new method for live-staining protists with DAPI and its application as a tracer of ingestion by walleye pollock (Theragra chalcogramma (Pallas)) larvae. J Exp Mar Biol Ecol 204:43-57

Li A, Stoecker DK, Coats DW, Adam EJ (1996) Ingestion of fluorescently labeled and phycoerythrin-containing prey by mixotrophic dinoflagellates. Aquat Microb Ecol 10: $139-147$

Matsuyama Y, Uchida T, Honjo T (1997) Toxic effects of the dinoflagellate Heterocapsa circularisquama on clearance rate of the blue mussel Mytilus galloprovincialis. Mar Ecol Prog Ser 146:73-80

McManus GB, Fuhrman JA (1988) Clearance of bacteriasized particles by natural populations of nanoplankton in the Chesapeake Bay outflow plume. Mar Ecol Prog Ser 42: 199-206

Nakamura Y, Suzuki S, Hiromi J (1995) Growth and grazing of a naked heterotrophic dinoflagellate, Gyrodinium dominans. Aquat Microb Ecol 9:157-164

Nakamura Y, Suzuki S, Hironi J (1996) Development and collapse of a Gymnodinium mikimotoi red tide in the Seto Inland Sea. Aquat Microb Ecol 10:131-137

Putt M (1991) Development and evaluation of tracer particles for use in microzooplankton herbivory studies. Mar Ecol Prog Ser 77:27-37

Rublee PA, Gallegos CL (1989) Use of fluorescently labelled algae (FLA) to estimate microzooplankton grazing. Mar Ecol Prog Ser 51:221-227

Stoecker DK (1988) Are marine planktonic ciliates suspension-feeders? J Protozool 35:252-255

Stoecker D, Guillard RRL, Kavee RM (1981) Selective predation by Favella ehrenbergii (Tintinnina) on and among dinoflagellates. Biol Bull 160:136-145

Stoecker DK, Cucci TL, Hulburt EM, Yentsch CM (1986) Selective feeding by Balanion sp. (Ciliata: Balanionidae) on phytoplankton that best support its growth. J Exp Mar Biol Ecol 95:113-130

Stoecker DK, Silver MW, Michaels AE, Davis LH (1988) Obligate mixotrophy in Laboea strobila, a ciliate which retains chloroplasts. Mar Biol 99:415-423

Stoecker DK, Taniguchi A, Michaels AE (1989) Abundance of autotrophic, mixotrophic and heterotrophic planktonic ciliates in shelf and slope waters. Mar Ecol Prog Ser 50: $241-254$

Taniguchi A, Takeda Y (1988) Feeding rate and behavior of the tintinnid ciliate Favella taraikaensis observed with a high speed VTR system. Mar Microb Food Webs 3:21-34

Verity PG (1988) Chemosensory behavior in marine planktonic ciliates. Bull Mar Sci 43:772-782

Submitted: September 14, 1999; Accepted: February 8, 2000

Proofs received from author(s): April 13, 2000 